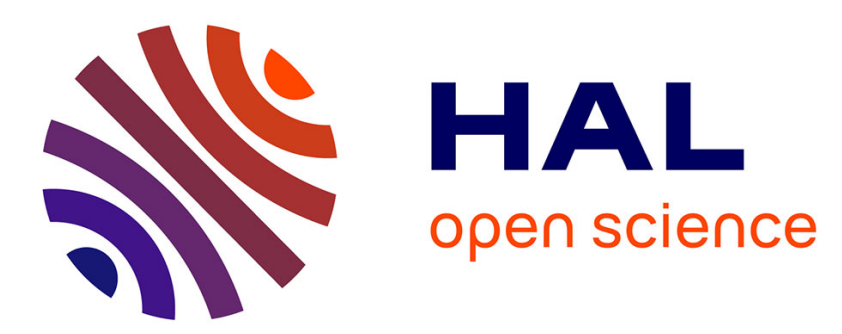

\title{
Exotic weed contamination in Swiss agriculture and the non-agriculture environment
}

\author{
Bohren
}

\section{To cite this version:}

Bohren. Exotic weed contamination in Swiss agriculture and the non-agriculture environment. Agronomy for Sustainable Development, 2011, 31 (2), pp.319-327. 10.1051/agro/2010017 . hal-00930454

\section{HAL Id: hal-00930454 \\ https://hal.science/hal-00930454}

Submitted on 1 Jan 2011

HAL is a multi-disciplinary open access archive for the deposit and dissemination of scientific research documents, whether they are published or not. The documents may come from teaching and research institutions in France or abroad, or from public or private research centers.
L'archive ouverte pluridisciplinaire HAL, est destinée au dépôt et à la diffusion de documents scientifiques de niveau recherche, publiés ou non, émanant des établissements d'enseignement et de recherche français ou étrangers, des laboratoires publics ou privés. 


\title{
Review article
}

\section{Exotic weed contamination in Swiss agriculture and the non-agriculture environment*}

\author{
Christian BOHREN** \\ Research Station Agroscope Changins-Wädenswil ACW, route de Duillier, 1260 Nyon, Switzerland
}

(Accepted 19 March 2010) (Published online: 3 September 2010)

\begin{abstract}
Swiss farmers nowadays gain a great part of their income from ecological compensation areas, especially wildflower strips, instead of cash crops. Mainly Crisium arvense and invasive alien plant species such as Solidago ssp. are abundant in ecological compensation areas; Reynoutria ssp. is highly abundant in non-agricultural zones and increasingly abundant in agricultural fields; Ambrosia artemisiifolia is an annual weed in agriculture and mandatory to control in Switzerland. Here, we present the results of a survey of wildflower strips in ecological compensation areas. The results of field and pot trials with Solidago, Reynoutria and Ambrosia species are also presented, as well as strategies for Ambrosia control and the information campaign on Ambrosia in Switzerland. The major result we found that was that wildflower strips are infested by noxious weeds and invasive alien plant species. Infestation is in most cases not as alarming as it is sometimes presented in the daily press. Solidago, Reynoutria and Ambrosia species cannot always be fully killed by one control measure. A check of efficacy and repeated control is necessary to achieve complete killing. Abundance of these species in non-agricultural zones makes weed control methods subject to public discussions. The main outcome of the work with weed species interfering in agricultural and non-agricultural zones is the conclusion that guidelines are needed to concentrate financial and human resources on real problems such as public health or damage to infrastructure. Three elements - a collection of weak point sheets for noxious endemic and exotic weed species, a detailed list of costs for control methods, and a detailed list of restrictions for use of control methods in environmental zones, both adapted to a country or region - would allow any functionary in any region to choose adequate control methods.
\end{abstract}

invasive plants / weed control / Reynoutria / Solidago / Ambrosia

\section{Contents}

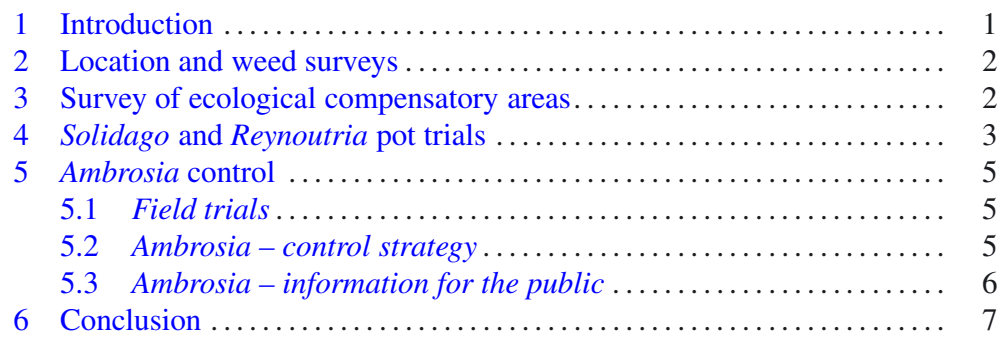

\section{INTRODUCTION}

Weeds have disturbed agricultural production since man started farming. Farmers have developed a sophisticated system to control weeds in all types of cash crops. Annual and

* Selected article from the XIIIth International Conference on Weed Biology, Dijon, France, 2009.

** Corresponding author: christian.bohren@acw.admin.ch perennial weeds are mostly well controlled with herbicides or with mechanical weed control. Swiss farmers nowadays gain a great part of their income from ecological compensation areas instead of cash crops. Ecological compensation (Bund, 2009) is a programme of the Swiss government to supplement conservation areas with small-scale habitats for plants and animals in the cultural landscape such as hedges, extensively farmed grasslands or wildflower strips in arable fields 
Table I. Assessment scheme for classification of weed infestation wildflower strips.

\begin{tabular}{ll}
\hline Classification of ground cover & Assessment for species abundance \\
\hline$<1 \%$ & not present \\
$1-5 \%$ & present: control measure is expected \\
$6-10 \%$ & abundant: control measure is necessary to maintain ecological quality \\
$11-33 \%$ & critical abundance: control measures risk destroying the flora of the strip \\
$>33 \%$ & strip is worthless for ecological compensation and loses right for subsidies \\
\hline
\end{tabular}

(Vonlanthen et al., 2005). Especially wildflower strips have been an important part of Swiss agricultural policy for about 15 years and compulsory for farmers to achieve proper income (Häni, 2008). The government is paying in 2010 some CHF 2800 per year and hectare (Bund, 2009).

A wildflower strip is sown with special seed mixtures and it needs maintenance, such as weed control, during its life time. A strip must remain for at least 6 years, after which it can be re-cultivated. This long period allows perennial weeds and invasive alien plant species (IAP) to establish if the wildflower strip is not well controlled. Mainly Crisium arvense (Cirsium) (Niederstrasser and Gerowitt, 2008) and IAP such as Solidago ssp. (Solidago) (Jeanmonod, 2005) are abundant in ecological compensation areas; Reynoutria ssp. (Reynoutria) (Child and Wade, 2000) is highly abundant in non-agricultural zones and increasingly abundant in agricultural fields; Ambrosia artemisiifolia (Ambrosia) (Schröder and Meinlschmidt, 2009) is mandatory to control in Switzerland (Bund, 2006).

Cirsium and Reynoutria are not easy to control in arable fields; Ambrosia is far from widespread, but it is well known to the public because of its highly allergenic pollen. Solidago is often abundant in ecological compensation areas but not in arable fields. Chemical and mechanical weed control of these species in ecological compensation areas as well as in nonagricultural areas is always in discussion.

The objective of this review is to present our ongoing research on control methods for the mentioned species. Field trials and pot trials are presented, as well as the information campaign on Ambrosia and its results. A national observation network has been established for observing weed infestation in Ecological Compensation Areas. The results of trials and a survey are presented and discussed; conclusions are drawn for weed control in non-agricultural zones.

\section{LOCATION AND WEED SURVEYS}

The Research Station Agroscope Changins-Wädenswil (ACW) started action on exotic weed infestation in three ways: a survey of weed species including Cirsium, Solidago, Reynoutria and Ambrosia was executed in a number of wildflower strips in several regions of Switzerland from 2003 to 2005. At the same time we started a programme for testing almost all herbicides registered in Switzerland in field trials on their efficacy on Ambrosia. In parallel, we informed the public with press conferences on the Ambrosia life cycle and the best control strategy; almost 650000 flyers on the strategy of Ambrosia control have been distributed in all official languages in Switzerland, a country with a population of 7.2 million.
We organised courses on identification and control methods of Ambrosia. Furthermore, we started a series of pot trials in a glasshouse to search for a herbicide with persistent efficacy against Solidago and Reynoutria.

Details on the methods and results of the survey of wildflower strips, on Ambrosia field trials and the information campaign, and on Solidago and Reynoutria pot trials are given in the following paragraphs.

\section{SURVEY OF ECOLOGICAL COMPENSATORY AREAS}

Over 3 years a nationwide observation network was established. Between 2003 and 2005 data on almost 200 wildflower strips were collected in several regions of Switzerland (Geneva, Vaud, Bern, Solothurn, Zurich and Ticino). 54 strips were observed in two and more years, which led to 294 inventories. Each strip was orbited once by foot. Large plots were additionally traversed on the diagonal. Most of the observations took place after the harvest of cereals when access to wildflower strips was eased. Weeds in strips were well visible at this time. We walked around the wildflower strips, and registered the estimated percentage of ground cover and plant height of the species.

The installation of such areas for ecological compensation on arable land raises concerns about their potential to contribute to the dissemination of weeds and neophytes. Table I shows the criteria used for classifying a weed species. These criteria express the importance of weed infestation for the ecological quality of a wildflower strip. Depending on weed species, ground cover from $11 \%$ onwards could bear the risk for the wildflower strip of being eliminated from governmental subsidies for ecological compensation.

The majority of wildflower strips presented an interesting or even excellent botanical composition (Delabays et al., 2007b). The inventories were limited to the restricted assessment of the actual number of noxious weeds such as $C$. arvense, Rumex obtusifolius, Senecio erucifolius, S. jacobeae, Galium aparine, Agropyron repens, Convolvulus arvensis and Equisetum arvense. Neophytes such as $A$. artemisiifolia, S. canadensis, S. gigantea, Reynoutria ssp., Oenothera biennis, H. mantegazzianum, Senecio inaequidens and Buddleja davidii were registered. Several weeds were regularly noted as abundant, especially $C$. arvense, $R$. obtusifolius, A. repens and C. arvensis. We estimated that $5 \%$ of the wildflower strips presented a critical weed situation - mainly because of $C$. arvense (Tab. II). 
Table II. Number of wildflower strips of ecological compensatory areas related to abundance of Cirsium arvense in various Swiss regions. Percentage of classes given regarding total number of strips; data from national observation network (2003-2005).

\begin{tabular}{lcccccc}
\hline Region & \multicolumn{5}{c}{ Classification of ground cover in \% } \\
\cline { 3 - 6 } & & $<1 \%$ & $1-5 \%$ & $5-10 \%$ & $11-33 \%$ & $>33 \%$ \\
\hline \multirow{2}{*}{ Geneva } & 36 & 15 & 19 & 1 & 1 & 0 \\
Vaud & 82 & 32 & 47 & 3 & 0 & 0 \\
Bern & 15 & 8 & 4 & 2 & 1 & 0 \\
Limpachtal & 27 & 18 & 8 & 0 & 0 & 1 \\
Rafzer Feld & 123 & 63 & 53 & 2 & 3 & 2 \\
Ticino & 10 & 10 & 0 & 0 & 0 & 0 \\
Total number of strips & 293 & 146 & 131 & 8 & 5 & 3 \\
Percentage of total number & $100 \%$ & $50 \%$ & $44 \%$ & $3 \%$ & $2 \%$ & $1 \%$ \\
\hline
\end{tabular}

Table III. Number of wildflower strips of ecological compensatory areas related to abundance of Solidago ssp. in various Swiss regions. Percentage of classes given regarding total number of strips; data from national observation network (2003-2005).

\begin{tabular}{lcccccc}
\hline Region & \multicolumn{5}{c}{ Percentage of ground cover } \\
\cline { 3 - 6 } & & $<1 \%$ & $1-10 \%$ & $11-33 \%$ & $33-65 \%$ & $>65 \%$ \\
\hline \multirow{2}{*}{ Geneva } & 36 & 11 & 20 & 4 & 1 & 0 \\
Vaud & 82 & 65 & 17 & 0 & 0 & 0 \\
Bern & 15 & 10 & 5 & 0 & 0 & 0 \\
Limpachtal & 27 & 24 & 2 & 1 & 0 & 0 \\
Rafzer Feld & 123 & 58 & 58 & 3 & 4 & 0 \\
Ticino & 10 & 9 & 0 & 0 & 0 & 1 \\
Total number of strips & 293 & 177 & 102 & 8 & 5 & 1 \\
Percentage of total number & $100 \%$ & $60 \%$ & $35 \%$ & $3 \%$ & $2 \%$ & $0.5 \%$ \\
\hline
\end{tabular}

The results of Cirsium are given because this weed is always remarkable when abundant. It quickly leads to a bad image in judging the quality of a wildflower strip. Cirsium data correspond to data on Solidago. This species was abundant in about one-third of all observed strips (Tab. III). The values are comparable, but the subjective evaluation of these species might be different. Control methods for Cirsium are well known, while control methods for Solidago are now under investigation. Other neophytes have not been observed so far.

There was no reason to separate IAP and endemic weeds concerning their observation. Even the approach to control methods against perennial IAP and perennial endemic weeds or annuals, respectively, is not different.

The installation of a wildflower strip in the scope of the ecological compensation system is one of the major elements for a Swiss farmer to achieve full farming income. Undoubtedly, those elements enhance the quality of biodiversity in the landscape. The infestation of wildflower strips by noxious weeds and IAP exists but it is in most cases not as alarming as it is sometimes presented in the daily press. An increasing abundance is registered for Ambrosia, which is on one hand a neophyte with an invasive character, and on the other hand a summer annual agricultural weed. Other species such as $H$. mantegazzianum, C. esculentus, A. theophrasti and
S. inaequidens are sporadically abundant in agricultural fields (Delabays et al., 2007a). This is one reason why we started a repetition of the survey in 2009 . A new survey will give some information about the correlation of wildflower strips and the spread potential of neophytes. It will also provide some new information on the level of maintenance of wildflower strips by farmers.

\section{SOLIDAGO AND REYNOUTRIA POT TRIALS}

In Swiss agriculture north of the Alps Solidago and Reynoutria species cause problems for farmers. Solidago invades wildflower strips, which are supposed to be kept for at least 6 years. Solidago disappears quickly after re-cultivation due to soil tillage. The problem for agriculture is not only a biological one, but an administrative one. Up to $33 \%$ of ground cover of Solidago is tolerated in a wildflower strip (Bund, 2009). It is defined as an invasive plant and is therefore listed on the "blacklist" of the Commission for Wild Plant Conservation CPS/SKEW (Weber et al., 2005). According to the Ordinance on the Handling of Organisms in the Environment (Release Ordinance, RO) it is a forbidden plant. Abundance in the government-subsidised wildflower strips is therefore 
Table IV. Herbicide efficacy results of pot trials (2008) on Solidago canadensis. Details on efficacy (in percent compared with untreated) of plants up to 111 days after treatment (DAT) and on rhizomes one year after treatment are given.

\begin{tabular}{|c|c|c|c|c|c|c|c|}
\hline \multirow[t]{2}{*}{ Herbicide $(\mathrm{g} / \mathrm{L})$} & \multirow[t]{2}{*}{ Application date } & \multirow[t]{2}{*}{ Dosage } & \multirow{2}{*}{$\frac{\text { Plant height }(\mathrm{cm})}{\text { 0 DAT }}$} & \multicolumn{2}{|c|}{ Herbicidal efficacy (\%) } & \multicolumn{2}{|c|}{ Remarks } \\
\hline & & & & 22 DAT & $111 \mathrm{DAT}$ & plant 72 DAT & rhizome 365 DAT \\
\hline Untreated & April 22, 2008 & & $10-15$ & $0 \%$ & $0 \%$ & 5 living & 5 living \\
\hline Glyphosate (360) & April 22, 2008 & $2 \%$ & $10-15$ & $100 \%$ & $100 \%$ & 5 dead & 5 dead \\
\hline Fluroxypyr (100) & April 22, 2008 & $1 \%$ & $10-15$ & $75 \%$ & $100 \%$ & 5 dead & 5 dead \\
\hline +Aminopyralid (30) & & & 0 DAT & 8 DAT & 104 DAT & 104 DAT & 365 DAT \\
\hline Untreated & May 6, 2008 & & $25-25$ & $0 \%$ & & 5 living & 5 living \\
\hline Glyphosate (360) & May 6, 2008 & $2 \%$ & $20-25$ & $75 \%$ & $80 \%$ & 4 living & 1 dead \\
\hline $\begin{array}{l}\text { Fluroxypyr (100) } \\
+ \text { Aminopyralid (30) }\end{array}$ & May 6, 2008 & $1 \%$ & $20-25$ & $65 \%$ & $100 \%$ & 4 dead & 5 dead \\
\hline
\end{tabular}

Table V. Herbicide efficacy results of pot trials (2008) on Reynoutria japonica. Details on efficacy (in percent compared with untreated) of plants up to 72 days after treatment (DAT) and on rhizomes one year after treatment are given.

\begin{tabular}{|c|c|c|c|c|c|c|c|}
\hline \multirow[t]{2}{*}{ Herbicide $(\mathrm{g} / \mathrm{L})$} & \multirow[t]{2}{*}{ Application date } & \multirow[t]{2}{*}{ Dosage } & \multirow{2}{*}{$\frac{\text { Plant height }(\mathrm{cm})}{0 \text { DAT }}$} & \multicolumn{2}{|c|}{ Herbicidal efficacy $(\%)$} & \multicolumn{2}{|c|}{ Remarks } \\
\hline & & & & 8 DAT & $66 \mathrm{DAT}$ & plant $66 \mathrm{DAT}$ & rhizome 365 DAT \\
\hline Untreated & April 29, 2008 & & $50-60$ & $0 \%$ & & 5 living & 5 living \\
\hline Glyphosate (360) & April 29, 2008 & $2 \%$ & $50-60$ & $20 \%$ & $60 \%$ & 4 living & 5 living \\
\hline \multirow{2}{*}{$\begin{array}{l}\text { Fluroxypyr (100) } \\
\text { +Aminopyralid (30) }\end{array}$} & April 29, 2008 & $1 \%$ & $50-60$ & $15 \%$ & $90 \%$ & 4 dead & 2 dead \\
\hline & & & 0 DAT & 15 DAT & 72 DAT & 72 DAT & 365 DAT \\
\hline Untreated & May 6, 2008 & & $70-100$ & $0 \%$ & $0 \%$ & 5 living & 5 living \\
\hline Glyphosate (360) & May 6, 2008 & $2 \%$ & $70-100$ & $40 \%$ & $100 \%$ & 5 dead & 1 dead \\
\hline Fluroxypyr (100) & May 6, 2008 & $1 \%$ & $70-100$ & $65 \%$ & $100 \%$ & 5 dead & 5 dead \\
\hline +Aminopyralid (30) & & & & & & & \\
\hline
\end{tabular}

problematic. Solidago propagates with seeds and with rhizomes (Guo et al., 2009).

Reynoutria is rarely a weed in arable land, but it can be very disturbing in grazing areas. It is highly abundant in the rest of the country. The demand for a suitable control strategy in building zones - even in sensible zones along watercourses or nature reserves - is high.

Samples of Solidago and Reynoutria rhizomes were dug out from the field before sprouting and planted in 15-1 and 8-1 pots, respectively, filled with our soil substrate in early spring. Herbicides were applied with a knapsack sprayer at normal dose, $400 \mathrm{~L} /$ ha water, using Teejet nozzles on two application dates for Solidago, April 22 and May 6, 2008, at plant height of 10-15 cm and 20-25 cm, respectively. Reynoutria was treated with the same knapsack sprayer on April 29 and May 6, 2008, at plant height of 70-100 cm and 50-60 cm, respectively. Each experiment had 4 replicates. The percentage of herbicidal efficacy was visually estimated several times. All rhizomes were checked for viability - visual control of new sprouts after washing the rhizome with water - one year after the treatment. For these preliminary trials we chose normal herbicide doses.

Table IV gives the results of pot trials in 2008 on Solidago. Plants of 20-25 cm height treated with glyphosate were not completely killed one year after the application. A complete kill - plants and rhizomes - resulted after the glyphosate treatment on younger plants. The mixture of fluroxypyr and aminopyralide did not allow any treated plants to survive one year after application. Table $\mathrm{V}$ gives the results of the Reynoutria trials. Plants of 70-100 cm height treated with glyphosate were not completely killed one year after the application, but were completely killed with the mixture of fluroxypyr and aminopyralide. Plants of 50-60 cm height treated with glyphosate were completely killed; plants treated with the mixture of fluroxypyr and aminopyralide were not completely killed one year after the application.

Solidago can be a weed in ecological compensatory areas, especially wildflower strips, which remains for at least 6 years in the field. In this period a Solidago population can destroy the ecological value of the area, which leads to a loss of income for the farmer. A suitable control method in wildflower strips still needs to be developed.

In non-agricultural areas Solidago causes similar problems to Reynoutria. Both species are by definition invasive; they bear the risk of damaging the biodiversity and the infrastructure. The complete destruction of rhizomes of Solidago or Reynoutria could locally solve a problem of causing damage to infrastructure or endangering the biodiversity. One of the main 
problems is its abundance in non-agricultural areas along water or traffic lines. A check of the viability of rhizomes in our pot trials one year after the application was disillusioning. Herbicides may not completely kill plants and rhizomes in one application. The combination of herbicide use together with a mechanical technique might be an important factor for successful destruction of the rhizomes. Mechanical control is expensive and is often difficult or impossible to do. But it may always be the only control measure where use of herbicides is forbidden.

The pot trials were carried out with accidentally found rhizomes; especially the plant material for Reynoutria was very inhomogeneous. In a second series of experiments in 2009 we used potted Reynoutria plants grown in vitro from tissue culture. The homogeneity of the growing size of these plants was better; the experiments are still going on.

\section{AMBROSIA CONTROL}

Ambrosia is an annual dicotyledonous plant of North American origin. The species was presented as a new agricultural weed at the 9th EWRS Symposium in Budapest in 1995 (Medzihradszky and Járai-Komlódi, 1995). It was predicted that this problematic weed would spread in the near future into other European countries. The history and current situation of Ambrosia plant and pollen expansion was discussed by Rybníček and Jäger (2001). Today Ambrosia is an invasive plant in several European regions such as the Balkan states and Hungary, the Po Valley in Italy and the Rhône-Alpes region in France (Déchamp et al., 2009). The invasion pattern of Ambrosia in France was discussed by Chauvel et al. (2006). An increasing abundance has been observed in Switzerland in the last couple of years.

In infested European regions people suffer increasingly from ragweed allergies and asthma as the quantity of pollen in the air rises. This increase in pollen rate is caused by an enormous and fast propagation of ragweed in agricultural fields and non-agricultural areas and a rapid distribution to non-infested areas (Clot et al., 2002, 2005). Ambrosia's invasion pathways and its impact on human health fully depend on human activities. With soil movements, and traffic and transport of goods, seeds are distributed to all zones of human surroundings. Ambrosia is perfectly able to outlive a rather long period of competition in wheat fields until it starts to develop new leaves, pollen and seeds in stubble field (Delabays et al., 2005). Its high capacity for reproduction and its relatively low impact on the species diversity of a plant community (Fumanal et al., 2008) predestine Ambrosia as an agricultural weed. Agriculture should never be found guilty of not being capable of controlling weeds which harm human health.

In Germany, a comparable action of nation-wide monitoring and a public information campaign on Ambrosia started in 2007 (Starfinger, 2008).

\subsection{Field trials}

Field trials were carried out in a field with a natural, dense and almost homogenous Ambrosia population. A band of $6 \mathrm{~m} \times 210 \mathrm{~m}$ was separated from the farmer's field and divided into small plots. Density of Ambrosia was normally $>150$ plants per $\mathrm{m}^{2}$. Herbicides were applied with a knapsack sprayer in $3 \mathrm{~m} \times 2.5 \mathrm{~m}$ in 4 replications. An untreated band of $1 \mathrm{~m}$ separated every two replications. Herbicide efficacy was visually estimated in all replications together with an untreated control. The herbicides were applied at normal dose at application time for the crop according to the label.

Cutting was done with a brush cutter. Small plots for cutting trials were sized $3 \mathrm{~m} \times 6 \mathrm{~m}$ and normally replicated three times. In the trial with a combination of mechanical and chemical control plants were treated 4, 6, 8 and 10 weeks after cutting, respectively. An early cut was done before pollen production; a second cut was done 2 weeks later. A late cut was done before the beginning of seed production.

For viability tests of seeds, branches of untreated Ambrosia or sprouts after an insufficient control measure were sampled on defined dates from the field and dried in the lab. Grains were threshed out during the winter time. The grains were kept for 5 weeks in the fridge at $4{ }^{\circ} \mathrm{C}$ mixed with watered quartz sand to break the dormancy. Viability of grains was tested in Petri dishes wetted with blotting paper. Normally 50 grains were put into a Petri dish and kept in the climate cabin with $14 \mathrm{~h}$ of light and 18 (night) -21 (day) ${ }^{\circ} \mathrm{C}$ for 3 weeks for germination. Grains of cutting trials were caught in small funneltype receptacles incorporated in the soil, three per small plot. These grains were treated as described above. Germinating seeds were registered weekly. The viability rate was simply calculated from the total of germs.

\subsection{Ambrosia - control strategy}

The important weakness in the life cycle of this species is the fact that Ambrosia multiplies only through seeds. A simple control strategy can be formulated: prevent the formation of fertile seeds; non-lethal control measures allow Ambrosia to produce fertile seeds. The first experiences in Ambrosia control showed that one measure might not be sufficient to disrupt the life cycle. Herbicide application only did not always result in sufficient control in our field trials. Mechanical control such as cutting or mowing allowed Ambrosia in most of the cases to re-sprout and produce fertile seeds. A combination of mechanical and chemical treatment was the most successful method, as is shown in Table VI.

Successful control of Ambrosia is giving the plant no possibility to produce fertile seeds (Bohren et al., 2008). A cut before fertile seeds are produced and late enough in the year that no more seed production will be possible could be successful. This was the case after the cutting of Ambrosia plants on September 6th, 2005. The risk of failing with this method 
Table VI. Prevention of fertile grain production: results of field trials (2005-2007) with chemical, mechanical and combined methods; viability of grains produced after Ambrosia control.

\begin{tabular}{|c|c|c|c|c|c|c|c|}
\hline Year & Method & $\begin{array}{l}\text { Date } \\
\text { of cut }\end{array}$ & $\begin{array}{c}\text { Herbicide } \\
\text { application } \\
\text { date } \\
\end{array}$ & $\begin{array}{l}\text { Herbicide } \\
\text { a.i. (g/ha) }\end{array}$ & $\begin{array}{l}\text { Viable } \\
\text { grains } \\
\text { found }\end{array}$ & $\begin{array}{l}\text { Approx. } \\
\text { reduction } \\
\text { of grains }\end{array}$ & $\begin{array}{c}\text { Complete } \\
\text { disruption of } \\
\text { life cycle }\end{array}$ \\
\hline \multirow{3}{*}{2005} & \multirow{6}{*}{$1 \mathrm{cut}$} & 10.08 . & - & - & Yes & $5 \%$ & No \\
\hline & & 06.09. & - & - & No & $100 \%$ & Yes \\
\hline & & 14.09. & - & - & \multirow{4}{*}{ Yes } & $25 \%$ & \multirow{4}{*}{ No } \\
\hline \multirow{3}{*}{2006} & & 04.09. & - & - & & $50 \%$ & \\
\hline & & 11.09. & - & - & & $25 \%$ & \\
\hline & & 19.09. & - & - & & $25 \%$ & \\
\hline \multirow{2}{*}{2007} & \multirow{2}{*}{2 cuts } & 15.07. + 11.09. & - & - & \multirow{2}{*}{ Yes } & $25 \%$ & \multirow{2}{*}{ No } \\
\hline & & $15.08 .+15.09$ & - & - & & $75 \%$ & \\
\hline \multirow{4}{*}{2006} & \multirow{14}{*}{$\begin{array}{l}1 \text { cut }+ \\
\text { herbicide }\end{array}$} & \multirow{2}{*}{19.06.} & \multirow{4}{*}{31.08.} & Florasulam (5) & \multirow{6}{*}{ Yes } & $25 \%$ & \multirow{6}{*}{ No } \\
\hline & & & & Clopyralid (240) & & $25 \%$ & \\
\hline & & 2807 & & Florasulam (5) & & $50 \%$ & \\
\hline & & $28.0 \%$ & & Clopyralid (240) & & $50 \%$ & \\
\hline \multirow{10}{*}{2007} & & \multirow{7}{*}{15.07.} & 15.08. & Florasulam (5) & & $75 \%$ & \\
\hline & & & & Clopyralid (240) & & $50 \%$ & \\
\hline & & & 0109 & Glyphosate (2600) & \multirow{7}{*}{ No } & $100 \%$ & \\
\hline & & & 01.09. & Bromoxynil (108) & & & \\
\hline & & & & + Ioxynil (108) & & $100 \%$ & Yes \\
\hline & & & & + Fluroxypyr (108) & & & \\
\hline & & & & $\begin{array}{l}\text { Fluroxypyr (150) } \\
+ \text { Florasulam (3.8) }\end{array}$ & & $100 \%$ & \\
\hline & & 10.08. & 10.09 . & Glyphosate (2600) & & & \\
\hline & & \multirow{2}{*}{15.08 . } & \multirow{2}{*}{2.10} & Florasulam (5) & & $100 \%$ & \\
\hline & & & & Clopyralid (240) & Yes & $50 \%$ & No \\
\hline \multirow{4}{*}{2005} & \multirow{6}{*}{ herbicide } & - & 1706 & Glyphosate (1080) & \multirow{6}{*}{ Yes } & $5 \%$ & \multirow{6}{*}{ No } \\
\hline & & - & 17.00 & Clopyralid (120) & & $5 \%$ & \\
\hline & & - & 3108 & Glyphosate (2160) & & $50 \%$ & \\
\hline & & - & 31.08. & Glufosinat (1000) & & $50 \%$ & \\
\hline \multirow{2}{*}{2007} & & - & 25.07. & Glyphosate (2600) & & $75 \%$ & \\
\hline & & - & 15.08. & Florasulam (5) & & $50 \%$ & \\
\hline & & & & & & & seed rain \\
\hline 2006 & \multirow{2}{*}{ untreated } & - & - & - & - & - & $17^{\prime} 500$ \\
\hline 2007 & & - & - & - & - & - & $7^{\prime} 200$ \\
\hline
\end{tabular}

is quite high. One cut on July 15th, 2007, together with a herbicide treatment on September 1st completely disrupted the life cycle of Ambrosia, as well as a cut on August 10th and 15th, 2007, with following herbicide treatment on September 10th and October 2nd, respectively. More details are given in Table VI.

A herbicide which does not completely destroy the plant, but prevents the production of fertile seeds, could be very successful. A single herbicide treatment in combination with crop rotation and soil cultivation may successfully keep the number of Ambrosia weeds at a low level in agricultural practice; nevertheless, the prevention of seed production is essential. In non-agricultural areas the prevention of seed production is the only way to stop invasion. This can only be achieved by mechanical control, or - if herbicide use is allowed - by combined mechanical and chemical methods. Biological control measures are still under development.

\subsection{Ambrosia - information for the public}

A survey in Switzerland showed in 2005 that Ambrosia was already present in most parts of the country, mainly as single plants in residential zones. A few foci in agricultural zones were also known. ACW organised press conferences and published in various print media. During the 2006 to 2008 campaign Agroscope and Ambrosia were mentioned 660 times in print, radio or television media in Switzerland. This would be equivalent to the value of a 6-million Swiss franc publicity 
Table VII. Number of verified Ambrosia findings in canton Zurich, Switzerland (G. Popow, Strickhof Lindau, 2009).

\begin{tabular}{lccc}
\hline location & 2006 & 2007 & 2008 \\
private and allotment gardening & 397 & 65 & 19 \\
public greens, parks, root zone of trees & 63 & 13 & 4 \\
roadside and talus & 52 & 14 & 4 \\
grassland & 22 & 8 & 3 \\
acre & 8 & 11 & 13 \\
building site, dumpsites & 18 & 6 & 6 \\
car parking, industrial zone & 4 & 8 & 2 \\
rest (hedge, waterside, forest) & 30 & 22 & 0 \\
total & 594 & 147 & 51 \\
\hline
\end{tabular}

campaign (personal communication: C. Enz, ACW). Our information policy guaranteed maximum effect with a minimum of costs.

In the canton Zurich (Tab. VII) the number of verified plant findings declined remarkably in 2008 and 2009 (personal communication: G. Popow). One reason might be the bad climatic conditions for seed production in 2007. Another reason could have been the fact that people no longer announced Ambrosia findings in their garden. But many people are aware of the problem and are highly interested in Ambrosia control. Telephone calls by private citizens to the ACW research station for questions on Ambrosia are still frequent. 20 percent of the population suffers from hay fever allergies or asthma in heavily infested areas (Déchamp and Méon, 2002).

\section{CONCLUSION}

So-called "Ambrosia Groups" were initiated in various parts of Switzerland by agricultural services, meteorology agencies, medical services and governmental authorities (Bohren et al., 2006). ACW was asked to develop an Ambrosia control strategy, but we wanted to know the actual situation of Ambrosia invasion in the country. This is why ACW started a nationwide survey of Ambrosia and was soon respected as a centre of competence on that species.

Three heterogeneous species of neophytes are discussed in this paper: Ambrosia is an annual plant with an invasive character, invading various European regions, and harming the public's health with its highly allergenic pollen. Solidago is a perennial plant threatening biodiversity, but often loved as an ornamental plant. Reynoutria is a perennial plant also causing damage by destabilising banks of waterlines or slopes of traffic lines. Both are per definition invasive and widespread in many European regions.

Control of weeds and IAP in agricultural fields is done within the normal weed control measures for crops. In the case of noxious weeds such as Cirsium and IAP normal weed control measures are not always sufficient, therefore additional efforts are necessary. Successful control, meaning stopping infestation by these species, is possible only by multidisciplinary collaboration. People of all areas of life need to gather to fight undesirable plants. A good example was the described Ambrosia campaign in Switzerland during the last couple of years.
Weed control methods became subject to public discussions. This raised new questions. What is the reason why a species is dangerous? Why should a certain plant species be widely controlled by the general public? How could this be explained to laymen? How can eradication be explained to botanical laymen? Another question would be how to bundle the forces on the most dangerous species. In this context a classification of IAP and other noxious weeds would be helpful to intensify successful control. Species harming human health should always be controlled with first priority. Species damaging infrastructure should be controlled locally - if inevitability is given - by all means. Other invasive plants should be controlled locally if resources are available. Details of criteria for characterisation of the need for control of neophytes and other weeds are given in Table VIII.

Neophytes and other weeds must be well characterised (Sheppard et al., 2006). The factual and objective information of experts is presented in many types of lists and databases (Weber et al., 2005) and published on the internet. A lot of information work has to be done, to transfer the specialist knowledge to laymen to establish a collaboration involving other people than farmers. The term eradication needs to be reduced to a local problem. Reynoutria, for instance, should be eradicated locally where problems arise, but it can no longer be totally eradicated in the country. Practitioners need more detailed information about the life cycle of the species in question.

For better understanding of control measures the weak points in the life cycle of a plant need to be described. The weak point should always be the point of attack for control measures. As we have seen, the weak point for Ambrosia is the complete dependence on seed production. An important weak point for Reynoutria is the dependence on the survival of rhizomes. A more difficult case is Solidago for non-agricultural areas and permanent crops, because it propagates by rhizomes and seeds. For crop rotation areas the sensibility of Solidago rhizomes to soil cultivation is the weak point to follow up easily.

Politicians need guidelines in order to concentrate financial and human resources on real problems. Specialists and experts, however, should take into consideration that they do not create a negative spirit of a dangerous nature for the general public. But why not add endemic noxious weeds to the lists of neophytes and environmental weeds in order to concentrate on weed problems and hide the aspect of being alien? This would help to explain to the general public the importance and the neutrality of weed control.

Practical tools for an information concept on control of invasive and other noxious plant species, especially in nonagricultural areas, are needed not only in Switzerland. A proposal is to establish one sheet per species containing an exact description of the weak point and some general information on control measures. Possible control measures might be simply described as activities such as uprooting, excavation of soil, cutting, herbicide application, use of biological control agents and others. Secondly, consequences of incomplete control (reaction of the treated plant) must be mentioned on the sheet. Thirdly, the necessity of effective control and the 
Table VIII. Criteria for characterisation of the need for control of neophytes and other weeds and important plant species in Switzerland.

\begin{tabular}{|c|c|c|c|}
\hline Species & Origin $^{1}$ & Comment & Status (CPS-SKEW*) \\
\hline \multicolumn{4}{|c|}{ Harms human health and is mandatory to control } \\
\hline Ambrosia artemisiifolia & $\mathrm{n}$ & its pollen is highly allergenic, also causing asthma & blacklist \\
\hline \multicolumn{4}{|c|}{ Local control is urgent and necessary and prevents further invasion } \\
\hline Heracleum mantegazzianum & $\mathrm{n}$ & serious health hazards for humans by skin irritation & blacklist \\
\hline Senecio inaequidens & $\mathrm{n}$ & toxic for livestock & blacklist \\
\hline Abutilon theophrasti & $\mathrm{n}$ & difficult control with herbicides & \\
\hline \multicolumn{4}{|c|}{ Largely distributed; local control prevents significant local damage } \\
\hline Senecio jacobaea, S. aquaticus & $\mathrm{i}$ & toxic for livestock & \\
\hline Reynoutria ssp. & $\mathrm{n}$ & damages infrastructure, endangers biodiversity & blacklist \\
\hline Buddleja davidii & $\mathrm{n}$ & endangers biodiversity & blacklist \\
\hline Artemisia verlotiorum & $\mathrm{n}$ & endangers biodiversity & blacklist \\
\hline Impatiens glandulifera & $\mathrm{n}$ & causes erosion; endangers biodiversity & blacklist \\
\hline \multicolumn{4}{|c|}{ Sufficient control is possible within normal weed control methods } \\
\hline Solidago canadensis & $\mathrm{n}$ & endangers biodiversity & blacklist \\
\hline Cyperus esculentus & $\mathrm{n}$ & difficult control with herbicides & watchlist \\
\hline Rumex obtusifolius & $\mathrm{i}$ & difficult control with herbicides & \\
\hline Cirsium arvense & $\mathrm{i}$ & difficult control with herbicides & \\
\hline Convolvulus arvensis, $C$. sepium & $\mathrm{i}$ & difficult control with herbicides & \\
\hline Sorghum halepense & $\mathrm{n}$ & difficult control with herbicides & \\
\hline \multicolumn{4}{|c|}{ Early detection is necessary to prevent further distribution } \\
\hline Colchicum autumnale & $\mathrm{i}$ & toxic for livestock & \\
\hline Polygonum polystachia & $\mathrm{n}$ & causes erosion along rivers & blacklist \\
\hline Erigeron annuus & $\mathrm{n}$ & difficult control in vineyards & watchlist \\
\hline Bunias orientalis & $\mathrm{n}$ & difficult control with herbicides & watchlist \\
\hline Phedimus stoloniferum & $\mathrm{n}$ & difficult control with herbicides & watchlist \\
\hline Rubus armeniacus & $\mathrm{n}$ & endangers biodiversity & blacklist \\
\hline Helianthus tuberosus & $\mathrm{n}$ & endangers biodiversity & watchlist \\
\hline Aster novae-belgii & $\mathrm{n}$ & ornamental plant & \\
\hline Xanthium strumarium & $\mathrm{n}$ & difficult control with herbicides & \\
\hline Oenotera biennis & $\mathrm{n}$ & ornamental plant & \\
\hline
\end{tabular}

likeliness of after-treatment must be mentioned. But no figures and no further details are found on the sheet. A collection of sheets would represent all species relevant for a certain region or country. This collection needs to be accompanied by a first list containing details on costs of machines, labour and additional efforts for control methods. A second list needs to be established, containing detailed information on restrictions (adapted to a region or country) for use of herbicides or other control methods in all existing zones such as water surfaces, water lines, forest, traffic lines, public and private greens, agriculture and horticulture, industrial and residential zones, unproductive zones in mountain areas and others.

These three elements - a collection of weak point sheets for noxious endemic and exotic weed species, a detailed list of costs for control methods, and a detailed list of restrictions for use of control methods in environmental zones, both adapted to a country or region - would allow any functionary to choose adequate control methods. This information concept could work in every region and country. All existing information on IAP and noxious weeds would still be useful.

300 plant species of about 3000 in total in Switzerland are neophytes. Around 40 neophytes have the potential to invade the country, causing serious ecological and economic consequences. To fight against all these species with the same intensity and publicity would create a negative feeling for plants in the public. A classification of invasive neophytes - as is given in Table VIII - would help to handle the situation. Species harming human health such as Ambrosia or H. mantegazzianum should always be controlled as a first priority; manpower and resources should be concentrated on these species. Early detection of IAP should be organised in such a way that 
new species could be controlled in an early stage of invasion and finally be allocated to levels as proposed in Table VIII.

\section{REFERENCES}

Bohren C., Mermillod G., Delabays N. (2006) Common ragweed (Ambrosia artemisiifolia L.) in Switzerland: development of a nationwide concerted action, J. Plant Dis. Prot., Special Issue XX, 497-503.

Bohren C., Mermillod G., Delabays N. (2008) Ambrosia artemisiifolia L. - Control measures and their effects on its capacity of reproduction, J. Plant Dis. Prot., Special Issue XXI, 311-316.

Bund. (2006) Ordinance of Plant Protection, SR 916.20, AS 2006/2531, Classified Compilation of Federal Legislation, EDMZ Bern.

Bund. (2009) Ordinance of Direct Payments and Structures, SR 910.13, AS 2009/6091, Classified Compilation of Federal Legislation, EDMZ Bern.

Chauvel B., Dessaint F., Cardinal-Legrand C., Bretagnolle F. (2006) The historical spread of Ambrosia artemisiifolia L. in France from herbarium records, J. Biogeogr. 33, 665-673.

Child L., Wade M. (2000) The Japanese knotweed manual: the management and control of an invasive alien weed, Packard Publishing Ltd, Chichester, $123 \mathrm{p}$.

Clot B., Köhler B., Herren T., Udriet M., Hauser M., Sallin C., Moersen M., Gehrig R. (2005) Luftpollengehalt in der Schweiz 2004, MeteoSchweiz, Zürich 12, 77 p.

Clot B., Schneiter D., Tercier Ph., Gehrig R., Peeters A., Thibaudon M. (2002) Ambrosia pollen in Switzerland: local production or transport? Allergie et Immunologie 34, 126-128.

Déchamp C., Méon H. (2002) Ambrosia, Ambroisies, polluants biologiques, Edit. ARRPAM Lyon, 288 p.

Déchamp C., Méon H., Reznik S. (2009) Ambrosia artemisiifolia L. an invasive weed in Europe and adjacent countries: the geographical distribution (except France) before 2009, Ambroisie, The First International Ragweed Review 26, 24-46.

Delabays N., Bohren C., Mermillod G., Keimer C., Kündig C. (2005) L'ambroisie à feuilles d'armoise (Ambrosia artemisiifolia L.) en Suisse: aspects malherbologiques, Rev. Suisse Agric. 37, 17-24.
Delabays N., Mermillod G., Bohren C. (2007a) Plantes indésirables dans les jachères florales: résultats d'un reseau national d'observation, Rev. Suisse Agric. 39, 199-203.

Delabays N., Bohren C., Rometsch S. (2007b) Plantes envahissantes: quels enjeux pour l'agriculture ? Rev. Suisse Agric. 39, 285-290.

Fumanal B., Girod C., Fried G., Bretagnolle F., Chauvel B. (2008) Can the large ecological amplitude of Ambrosia artemisiifolia explain its invasive success in France? Weed Res. 48, 349-359.

Guo S.L., Jiang H.W., Fang F., Chen G.Q. (2009) Influences of herbicides, uprooting and use as cut flowers on sexual reproduction of Solidago Canadensis, Weed Res. 49, 291-299.

Häni F.J., Popow G., Reinhard H., Schwarz A., Voegeli U. (2008) Pflanzenschutz im nachhaltigen Ackerbau, Edition lmz, Zollikofen Schweiz, pp. 369-389.

Jeanmonod D. (2005) The situation in Switzerland, especially in Frenchspeaking Switzerland, Rev. Hortic. Suisse 78, 32-38.

Medzihradszky Z., Járai-Komlódi M. (1995) I came from America - My name is Ambrosia - Some feature of the ragweed, Proc. 9th EWRS (European Weed Research Society), Symposium Budapest 1995, pp. 57-63.

Niederstrasser J., Gerowitt B. (2008) Studies on the response of root fragment of Cirsium arvense on dryness, J. Plant Dis. Prot., Special Issue XXI, 369-372.

Rybníček O., Jäger S. (2001) Ambrosia (Ragweed) in Europe, Allergy and Clinical Immunology International 13, 60-66.

Schröder G., Meinlschmidt E. (2009) Investigations on control of common ragweed (Ambrosia artemisiifolia L.) with herbicides, Gesunde Pflanz. 61, 135-150.

Sheppard A.W., Shaw R.H., Sforza R. (2006) Top 20 environmental weeds for classical biological control in Europe: a review of opportunities, regulations and other barriers to adoption, Weed Res. $46,93-117$.

Starfinger U. (2008) The German action programme ambrosia? Nachr. Dtsch. Pflanzenschutzd. 60, 201-204.

Vonlanthen I., Ramseier H., Häni F. (2005) Vielfalt und Stabilität verschiedener Brachemischungen, Agrarforschung 12, 64-69.

Weber E., Köhler B., Gelpke G., Perrenoud A., Gigon A. (2005) Schlüssel zur Einteilung von Neophyten in der Schweiz in die Schwarze Liste oder die Watch-Liste, Bot. Helv. 115, 169-194. 